Отримано: 18 квітня 2018 р.

Прорецеензовано: 27 квітня 2018 р.

Прийнято до друку: 04 травня 2018 р.

e-mail: gmvmarichka@gmail.com

DOI: $10.25264 / 2311-5149-2018-9(37)-192-196$

Hryhorkiv M. Modeling of the single sectoral ecological economy dynamics in view of different tariffs on primary and secondary disposal of production pollution. Наукові записки Національного університету «Острозька академія». Серія «Економіка» : науковий журнал. Острог : Вид-во НаУОА, червень 2018. № 9(37). С. 192-196.

\title{
MODELING OF THE SINGLE SECTORAL ECOLOGICAL ECONOMY DYNAMICS IN VIEW OF DIFFERENT TARIFFS ON PRIMARY AND SECONDARY DISPOSAL OF PRODUCTION POLLUTION
}

The article proposes one of the possible approaches to simulate single sectoral one-product economy, which produces the main aggregate product and carries out primary and secondary utilization of the created pollution. The basic model and its modifications are formalized in the space of eco-economic variables, which include savings (liquid capital) of production enterprises owner (producer), the price of basic products and tariffs for primary and secondary pollution utilization. The developed models can be effective methodological tool in the further practice of eco-economic systems general dynamics research.

Key words: single sectoral economy, model, dynamics, primary and secondary utilization.

Григорків Марія Василівна,

кандидат економічних наук, доиент, доиент кафедри економіко-математичного моделювання

Чернівецького національного університету імені Юрія Федьковича

\section{МОДЕЛЮВАННЯ ДИНАМІКИ ОДНОСЕКТОРНОЇ ЕКОЛОГІЧНОЇ ЕКОНОМІКИ 3 УРАХУВАННЯМ РІЗНИХ ТАРИФІВ НА ПЕРВИННУ ТА ВТОРИННУ УТИЛІЗАЦІЮ ВИРОБНИЧОГО ЗАБРУДНЕННЯ}

У роботі запропоновано один із підходів до моделювання односекторної однопродуктової економіки, яка виробляє основний агрегований продукт $і$ здійснює первинну та вторинну утилізацію створеного забруднення. Базова модель і ї̈ модифікації формалізовані у просторі еколого-економічних змінних, до яких належать заощадження (ліквідний капітал) власника виробничих підприємств (виробника), ияіна на основну продукцію та тарифи на первинну і вторинну утилізацію забруднення. Для практики дослідження загальної динаміки еколого-економічних систем розроблені моделі можуть служити ефективним методологічним інструментарієм.

Ключові слова: односекторна економіка, модель, динаміка, первинна та вторинна утилізація.

\section{Григоркив Мария Васильевна,}

кандидат экономических наук, дочент, доцент кафедры экономико-математического моделирования

Черновиџкого начионального университета имени Юрия Федьковича

\section{МОДЕЛИРОВАНИЕ ДИНАМИКИ ОДНОСЕКТОРНОЙ ЭКОЛОГИЧЕСКОЙ ЭКОНОМИКИ С УЧЕТОМ РАЗНЫХ ТАРИФОВ НА ПЕРВИЧНУЮ И ВТОРИЧНУЮ УТИЛИЗАЦИЮ ПРОИЗВОДСТВЕННОГО ЗАГРЯЗНЕНИЯ}

\footnotetext{
В работе предложен один из подходов к моделированию односекторной однопродуктовой экономики, которая производит основной агрегированный продукт и осуществляет первичную и вторичную утилизацию созданного загрязнения. Базовая модель и ее модификаиии формализованы в пространстве эколого-экономических переменных, к которым относятся накопления (ликвидный капитал) владельиа производственных предприятий (производителя), цена на основную продукцию и тарифы на первичную и вторичную утилизацию загрязнения. Для практики исследования общей динамики эколого-экономических систем разработанные модели могут служить эффективным методологическим инструментарием.

Ключевые слова: односекторная экономика, модель, динамика, первичная и вторичная утилизация.
}

Problem setting. One of the most effective tools of scientific knowledge today is simulations. The modern science has made great progress in its various fields thanks to the method (or methods) of simulation. When this is in terms of economic and eco-economic systems, the most commonly used are such types of modeling as observation and its verbal description, economic experiment, game and machine imitation, mathematical 
modeling. In this case the mathematical modeling is an extremely powerful, efficient and economical means of cognition, the application of which in the context of the development of modern information technology has a special perspective. And first of all, these perspectives are connected with the research of complex dynamical systems, phenomena, processes, etc., to which the economy certainly belongs, the ecologization and socialization of which is a priority issue of a global scale.

The ecologization of economy is a process of continuous ecological improvement in all its spheres [1]. Thereat one should be able to assess the level of environmentalization of production and consumption of products, in particular, by means of quantitative estimation, the comparison of which allows to identify more effective areas of environmentalization. Constant assessment of the level of ecologization of the economy should become a system in the life of human society and be accompanied by the implementation of effective mechanisms of ecologization, which are connected in particular, with the construction and improvement of waste treatment facilities, modern facilities for utilization production, rational use of natural and labour forces, consumer and ecological culture of people, the latest technical and technological decisions of information, scientific and motivational support, etc. The fundamental program of implementation of ecologization processes of the economy is necessary for a systematic assessment of the level of ecologization and implementation of ecologization mechanisms. However, it is only possible to develop such a program on basis of appropriate scientific research, in particular on basis of models of ecologization of the economy.

The global models [1-7] are developed in the 1970s and 80s of the 20th century, which used fundamental knowledge of economics, ecology and society, as well as the experience gained by researchers in the construction of local models have had a significant impact on the development of eco-economic systems and in general of eco-economic policies in the world. The global problems or problems of global scale were the field of scientific interests of the participants of the Club of Rome, whose works were regularly published in the so-called «Reports» [5]. In the classification plan among global models there are both balance optimization and simulation models. The peculiarity of global models is that it reflects the attempt of their authors to substantiate scientifically the interaction of people and the environment on a global scale.

Analysis of recent researches and publications. Significant in order of importance of eco-economic research and their influence on the simulation of the processes of eco-economic interaction were also some models of a more local character, in particular the famous interdisciplinary model of the interdisciplinary eco-economic balance by Leontiev-Ford and its modifications [8], as well as various generalized models of ecological and economic balances [9-14]. The current state of the research of eco-economic systems, in particular their modeling is characterized by many serious achievements, the improvement of methodological and methodological tools for studying the specifics of eco-economic features in different regions, countries, etc., different approaches to evaluation and ways of achieving eco-economic equilibrium and sustainable development. Appreciating the research results obtained in this direction by foreign scientists we also emphasize the important achievements in economic modeling of environmental processes and systems by Ukrainian scientists, including the authors of papers [15-18] where dynamic models of inter-sectoral interaction between the economy and the environment were developed and investigated the relevant equilibrium and optimal trajectory environmental and economic development, also there was analyzed the possible construction of static and dynamic features of eco-economic behavior, established the approaches of modeling of the stochastic eco-economic models and their deterministic equivalents, there was studied the problem of balanced equilibrium prices and their impact on the eco-economic dynamics etc. However, the whole host of issues related to modeling of eco-economic interaction invite further investigations.

The purpose and tasks of the research. The notion of ecologization of the economy and the environment as a whole is inextricably linked with the concept of primary and secondary utilization of human pollution. In the case of industrial processes, the primary is the utilization of industrial waste, which is a byproduct of the main production and the secondary one is the utilization of production waste of auxiliary production, i.e., of the environmentally harmful remnants that were created during primary utilization. The purpose of the proposed research is to develop the models of the dynamics of single sectoral economy that takes into account is not only the minimum level of clustering of the elements of a society, which actually produces the main material products and the corresponding products of pollution, but also that the production of the main products and the disposal of pollutants are carried out by the same producers (owners) and workers. This specificity is reflected in the ratios developed by the here below models. Notionally, these models complement the results of the earlier researches $[19 ; 20]$ and are intended for the analysis the general dynamics of the eco- economic systems.

Setting objectives. In the case of the single sectoral economy, where along with the release of major material products, pollution is utilized, we can assume that the aggregate savings of both social groups (owners and workers) involved in production is permanent (i.e., we will assume that $M z_{M}+N Z_{N}=z=$ const, where $M$ and $N$ - number of owners and workers, $Z_{M}$ and $Z_{N}$ - savings (liquid capital) of the owner and the worker), but let us expand the range of functions of economic behavior, namely, the functions of demand for the main (aggregate) products $q$, production of the main products $f$, release of contamination during the production of basic products 
$\varphi$ and utilization of pollution, created during the release of the main products, $\psi$ add the function of release of contamination during primary utilization $\widetilde{\varphi}$ and the function of secondary utilization of pollution created during its primary utilization, $\widetilde{\varphi}$. Let $\alpha, \beta, \gamma$ and $\widetilde{\gamma}(0$ ъ $\alpha, \beta, \gamma, \gamma \leq 1, \alpha+\beta+\gamma+\gamma \leq 1)-$ are the share of savings of the owner of the main production for personal consumption, the output of the main (aggregate) products, the primary utilization of pollution, i.e., the pollution created during the production of basic products and the secondary utilization of pollution, that is, pollution created during its primary utilization. Let us denote the price of basic products, the tariff for utilization of primary and secondary pollution by $p, p^{(1)}$ and $\tilde{p}^{(2)}$. Then

$$
s_{\alpha}=\frac{\alpha z_{M}}{p}, \quad s_{\gamma}^{(1)}=\frac{\gamma z_{M}}{\tilde{p}^{(1)}},
$$

- consequently, purchasing, industrial, utilization during primary utilization, utilization during the secondary utilization of the capacity of the owner of the main production enterprises (single sectoral economy) powers. Let's assume that capital provision is the production of basic products or production capacity $S \beta$ also serves as an argument for the emission of contamination during the release of basic products, and the capital provision of primary utilization $s_{\gamma}^{(1)}$ - is also an argument for the function of primary utilization release, so the above capabilities are arguments for the above-mentioned functions of economic behavior, namely

$$
f=f(S \beta) \quad \varphi=\varphi(S \beta) \quad q=q\left(s_{d}\right)
$$

In the partial case, we can assume that

$\varphi(S \beta)=\lambda \mathrm{f}(S \beta)$

where $\lambda, \lambda(0 \leq \lambda, \bar{\lambda} \leq 1)$ - coefficients or shares of the corresponding release of pollution.

For the formalization of the equation of dynamics of owner's savings $Z_{M}$, who implements both primary and secondary utilization, we assume that utilization (primary and secondary) is carried out by the same workers who produce the main aggregate product. Let $d_{N}$ - wages of a worker in monetary units (m.u.). Taking into account that the owner's income depends on the taxable value of sales of basic goods (tax rate $\pi_{0}$ ), and costs - from expenditures on personal consumption of the basic products, wages and taxes of the workers (wage tax rate $\pi_{1}$ ), production needs of the main activity ( $\lambda_{\beta}$ - the share of costs for these needs), value added tax of the main production (tax rate $\pi_{2}$ ), production needs of primary and secondary utilization $\left(\lambda_{\gamma}\right.$ and $\lambda_{\tilde{\gamma}}$ - corresponding share of expenses for these needs), value added tax in the utilization processes (rate $\pi_{2}$ ), the equation for the dynamic variable $Z_{M}$ will be as the following:

$$
\begin{aligned}
& \frac{d z_{M}}{d t}=\frac{p\left(1-\pi_{0}\right)}{M}\left[M q\left(s_{\alpha}\right)+N q\left(s_{\widetilde{\alpha}}\right)+Q^{*}\right]-p q\left(s_{\alpha}\right)-\frac{N d_{N}\left(1+\pi_{1}\right)}{M}- \\
& -p\left(\lambda_{\beta}+\pi_{\mathbf{z}}\right) f\left(s_{\beta}\right)-\widetilde{p}^{(1)}\left(\lambda_{\gamma}+\pi_{\mathrm{z}}\right) \psi\left(s_{\gamma}^{(1)}\right)-\widetilde{p}^{(\mathbf{z})}\left(\lambda_{\widetilde{\gamma}}+\pi_{\mathrm{z}}\right) \widetilde{\psi}\left(s_{\widetilde{\gamma}}^{(2)}\right),
\end{aligned}
$$

where $s_{\widetilde{\alpha}}=\frac{\widetilde{\alpha} z_{N}}{p}=\frac{\widetilde{\alpha}\left(\bar{z}-M z_{M}\right)}{p N}$ - purchasing power of the worker $(0 \leq \tilde{\alpha} \leq 1), Q^{*}-$ the general demand for the main aggregate product of the other elements of the society and external market. Obviously, equation (2) takes into account the owner's costs for both primary and secondary utilization.

Assuming that the salary is proportional to the coefficients $\mu_{\beta} \mu_{\gamma}$ and $\mu_{\tilde{\gamma}}$ to the volumes of production of primary production, utilized pollution during primary utilization and utilized pollution during secondary utilization, that is, the owner's expenses on the salaries of the workers are equal

$\left[p \mu_{\downarrow} \beta f\left(s_{\downarrow} \beta\right)+p^{-\uparrow}((1)) \mu_{\downarrow} \gamma\left(S_{\downarrow} \gamma^{\uparrow}((1))\right)+p^{-\uparrow}((2)) \mu_{\downarrow} \gamma^{-} \psi_{\gamma^{\prime}}\left(S_{\downarrow} \gamma^{\uparrow}((2))\right)\right.$

m.u., then equation (2) is modified in the equation

$$
\begin{aligned}
& \frac{d z_{M}}{d t}=\frac{p\left(1-\pi_{0}\right)}{M}\left[M q\left(s_{\alpha}\right)+N q\left(s_{\tilde{\alpha}}\right)+Q^{*}\right]-p q\left(s_{\alpha}\right)-\left[p \mu_{\beta} f\left(s_{\beta}\right)+\tilde{p}^{(1)} \mu_{\gamma} \psi\left(s_{\gamma}^{(1)}\right)+\tilde{p}^{(2)} \mu_{\tilde{\gamma}} \tilde{\psi}\left(s_{\tilde{\gamma}}^{(2)}\right)\right] * \\
& *\left(1+\pi_{1}\right)-p\left(\lambda_{\beta}+\pi_{2}\right) f\left(s_{\beta}\right)-\tilde{p}^{(1)}\left(\lambda_{\gamma}+\pi_{3}\right) \psi\left(s_{\gamma}^{(1)}\right)-\tilde{p}^{(2)}\left(\lambda_{\tilde{\gamma}}+\pi_{3}\right) \tilde{\psi}\left(s_{\tilde{\gamma}}^{(2)}\right)=\frac{p\left(1-\pi_{0}\right)\left[N q\left(s_{\tilde{\alpha}}\right)+Q^{*}\right]}{M}- \\
& -p \pi_{0} q\left(s_{\alpha}\right)-\left[\left(1+\pi_{1}\right) \mu_{\beta}+\lambda_{\beta}+\pi_{\mathbf{2}}\right] p f\left(s_{\beta}\right)-\left[\left(1+\pi_{1}\right) \mu_{\gamma}+\lambda_{\gamma}+\pi_{\mathbf{3}}\right] \tilde{p}^{(1)} \psi\left(s_{\gamma}^{(1)}\right)- \\
& -\left[\left(1+\pi_{1}\right) \mu_{\tilde{\gamma}}+\lambda_{\tilde{\gamma}}+\pi_{3}\right] \tilde{p}^{(2)} \widetilde{\psi}\left(s_{\widetilde{\gamma}}^{(2)}\right) \text {. }
\end{aligned}
$$

The price of the aggregated product $p$ depends on the difference between the volume of demand and the supply of aggregate products, that is

$$
\frac{d p}{d t}=\theta_{\beta}\left[M q\left(s_{\alpha}\right)+N q\left(s_{\widetilde{\alpha}}\right)+Q \cdot-M f\left(s_{\beta}\right)\right]
$$

where $\theta_{\beta}$ - constant price adjustment factor $p$, which reflects the inertia of the market for main (aggregate) products.

Further, considering that $\tilde{p}^{(1)}$ and $\tilde{p}^{(2)}$ are two different dynamic variables, we simulate the equation of their dynamics. Since the change in each of them in time depends on the difference between the corresponding releases of industrial waste and the demand for their utilization, which coincides with the volume of their direct 
utilization (one of the main assumptions for single sectoral economy), these equations will take the form as:

$$
\begin{array}{r}
\frac{d \widetilde{p}^{(1)}}{d t}=\theta_{\gamma}^{(1)}\left[M \psi\left(s_{\gamma}^{(1)}\right)-M \varphi\left(s_{\beta}\right)\right] . \\
\frac{d \widetilde{p}^{(2)}}{d t}=\theta_{\widetilde{\gamma}}^{(2)}\left[M \widetilde{\psi}\left(s_{\widetilde{\gamma}}^{(2)}\right)-M \widetilde{\varphi}\left(s_{\gamma}^{(1)}\right)\right],
\end{array}
$$

where $\theta_{\gamma}^{(1)}$ and $\theta_{\widetilde{\gamma}}^{(2)}$ - stable coefficients of tariff regulation for primary and secondary utilization. If equations (5) and (6) take into account the dependences (1), then we obtain the equation

$$
\begin{aligned}
& \frac{d \widetilde{p}^{(1)}}{d t}=\theta_{\gamma}^{(1)}\left[M \psi\left(s_{\gamma}^{(1)}\right)-M \lambda f\left(s_{\beta}\right)\right] . \\
& \frac{d \widetilde{p}^{(2)}}{d t}=\theta_{\widetilde{\gamma}}^{(2)}\left[M \widetilde{\psi}\left(s_{\widetilde{\gamma}}^{(2)}\right)-M \widetilde{\lambda} \psi\left(s_{\gamma}^{(1)}\right)\right] .
\end{aligned}
$$

Supplementing the obtained equations (1)-(8) with initial conditions

$$
\begin{aligned}
& p\left(t_{0}\right)=p^{(0),} \\
& Z_{M}\left(t_{0}\right)=Z_{M}^{(0)}, \\
& \tilde{p}^{(1)}\left(t_{0}\right)=\tilde{p}^{(1,0)}, \\
& \tilde{p}^{(2)}\left(t_{0}\right)=\tilde{p}^{(2,0),}
\end{aligned}
$$

where amount $t_{0}, z_{M}^{(0)}, p^{(0)}, \quad \tilde{p}^{(1,0)}, \tilde{p}^{(2,0)}$ are considered given, we will have variants of models (2), (4)(6), (9); (2), (4), (7)-(9); (3), (4), (7)-(9). If you accept the model (2), (4)-(6), (9) for the base, it is easy to offer other variants of models. All these models are formalized by the systems of four differential equations and corresponding initial values of the studied dynamic variables, and separately describe the dynamics of tariffs for primary and secondary utilization.

Conclusions. One of the important assumptions in the development of dynamics models of single sectoral one-product economy is the assumption of the same or different tariffs for primary and secondary utilization. Obviously, each of these assumptions makes sense and is adequate in certain practical situations, but none of them can be universal and uniquely characterize the utilization processes of different levels of the hierarchy. In this regard, the dynamic models of eco-economic systems should take into account both variants of assumptions regarding tariffs for primary and secondary utilization.

The article deals with the dynamic models of single sectoral economy considering different tariffs for primary and secondary pollution utilization. Taking into account different tariffs does not only change the equation of dynamics of individual variables, it also increases the number of all variables per unit. On the one hand, the models with different tariffs can be the modifications of models with the same tariffs, but on the other hand they are independent models, which in fact formalize certain features and differences of primary and secondary utilization and their influence on the general dynamics of the invastigated eco-economic system. In this case, both classes of the models (both with the same and different tariffs) admit multiple variants of some initial assumptions, which leads to various modifications of models, which sometimes helps to get rid of the principal methodological and methodological complications associated with the construction of certain functions of ecoeconomic behavior and parameter identification. On the whole, the models with different tariffs expand the complex of dynamic models of eco-economic systems with primary and secondary pollution utilization and the possibility of their application in practice.

As to the process of formalization of the models referred to in this article, it is worth noting the fundamental role of the so-called functions of eco-economic behavior, i.e., the functions of demand for the main product, its release, the release of industrial waste and its utilization (primary and secondary). The construction of these functions is a separate stage in the development of structural models of eco-economic dynamics, the details of which can not be disclosed in terms of this material, limited by the corresponding scope of its presentation. We only note that the models of these functions reflect the well-known properties of demand, supply and output functions and to construct them classical approaches in modeling.

The problem of informational support of the proposed models and other models of eco-economic dynamics is worth particular attention. This problem is of special significance, it is actual and relevant to the particular object of the research, i.e., the specific eco-economic system of the region, country etc. Obviously, some of the parameters can be identified statistically if statistical sources are available, and the information they contain is adequate. Another part of the parameters can be established in the process of experimental investigations with models, for example, the factors of regulation of prices and tariffs, which is also a complicated task and requires the researcher to have practical skills and experience in conducting relevant simulation experiments. Though, in a number of cases, in particular for an unstable and corrupted economy, when there are no statistical data or the 
available data can not be trusted, the problem of identification is solved through the expert conclusions derived specifically for particular parameters. One of the practical criteria for the admissibility or adequacy of numerical values of parameters (as well as the model as a whole) is the comparison of computer-generated experiments with models of the basic regularities and trends of eco-economic dynamics with their real counterparts.

\section{References:}

1. Daly H. Ecological Economics. Principles and applications / H. Daly, J. Farley. - Washington : Island Press, 2004. $-454 \mathrm{p}$.

2. Форрестер Дж. Мировая динамика / Дж. Форрестер. - М. : Наука, 1978. - 168 с.

3. Пределы роста / [Медоуз Донелла Х., Медоуз Деннис Л., Рэндерс Йорген, Беренс III Вильям]; [пер. с анг. А. С. Саркисова / науч. ред. Д. Н. Кавтарадзе]; - М. : Изд-во МГУ, 1991. - 206 с.

4. Andrii Verstiak Stohastic and optimization models of pricing in eco-economic system / Andrii Verstiak, Vasyl Grygorkiv, Mariia Grygorkiv // International scientific research journal of Mykolas Romeris University, Lithuanian Academy of sciences, University of Wroclaw. - Vilnius. 2014 Vol. 8 (1). - P. 156-164.

5. Тадеєв Ю. П. Динамічні макроекономічні виробничі функції та їх двоїстий аналіз / Ю. П. Тадеєв // Сталий розвиток економіки. - 2012. - № 3. - С. 117-124.

6. Кузубов М. В. Моделюванн економічних і еколого-економічних процесів / М. В. Кузубов, О. М. Сдинак, Н. Л. Овандер. - К. : КСУ, 2010. - 170 с.

7. Онищенко А. М. Моделювання еколого-економічної взаємодії в процесі виконання рішень Кіотського протоколу : [монографія] / А. М. Онищенко. - Полтава : Полтавський літератор, 2011. - 398 с.

8. Ляшенко О. І. Математичне моделювання динаміки відкритої економіки: монографія / О. І. Ляшенко/ Рівне: Волинські обереги, 2005. - 360 с.

9. Ляшенко І. М. Економіко-математичні методи та моделі сталого розвитку / I. М. Ляшенко. - К. : Вища школа, 1999. - $236 \mathrm{c}$.

10. Youguo Zhang Impact of Urban and Rural Household Consumption on Carbon Emissions In China / Youguo Zhang. - Economic Systems Research. - Volume 25. - Issue 3. - 2013. - P. 287-299.

11. Daly H. E. Economics as a Life Science / H. E. Daly // The Journal of Political Economy. - 1968. - V.76. № 3. - P. 392-406.

12. Ayres P. U. Production, Consumption and Externalities / P. U. Ayres, A. V. Knesse // The American Economic Review. - 1969. - V.59(3). - P. 27-29.

13. Рюмина Е. В. Экологический фактор в экономико-математических моделях / Е. В. Рюмина. - М. : Наука, 1980. - $166 \mathrm{c}$.

14. Willen I. A model of Economic System-ecosystem Interaction / I. Willen // Journal Environment and Planing. - 1973. - V.15. - P. 35-44.

15. Grygorkiv V.S. An aggregated model of optimization of economy with an ecological-economical criterion / Grygorkiv V.S. // Journal of Cybernetics and Systems Analysis. - Volume 35, Issue 4. - 1999. - P. 619-627.

16. Grigorkiv V.S. Simulation of a multisector ecological and economic system / Grigorkiv V.S. // Journal of Cybernetics and Systems Analysis. - Volume 35, Issue 3. - 1999. - P. 470-478.

17. Grigorkiv V.S. Simulation of Ecological and Economical Structural-Type Functions / Grigorkiv V.S. // Journal of Cybernetics and Systems Analysis. - Volume 38, Issue 1. - 2002. - P. 137-142.

18. Hrygorkyv V.S. Some approaches to modelling prices in an ecological-economic system / Hrygorkyv V.S. // Journal of Cybernetics and Systems Analysis. - Volume 45, Issue 1. - 2009. - P. 1-7.

19. Vasiliy S. Grygorkiv, Mariya V. Grygorkiv Modeling the Dynamics of Ecological-Economic Systems Based on Economic Structuring a Society. Part I / Vasiliy S. Grygorkiv, Mariya V. Grygorkiv // Journal of Automation and Information Sciences. - Volume 47, Issue 4. - 2015. - P. 18-27.

20. Vasiliy S. Grygorkiv, Mariya V. Grygorkiv Modeling the Dynamics of Ecological-Economic Systems Based on Economic Structuring a Society. Part II / Vasiliy S. Grygorkiv, Mariya V. Grygorkiv // Journal of Automation and Information Sciences. - Volume 47, Issue 6. - 2015. - P. 33-40. 